\title{
Application of chemography for evaluating the workability of hard alloy cutting plates
}

\author{
Alexander Salenko ${ }^{1} \bullet$ Mykhailo Elizarov $^{2} \bullet$ Viktor Shchetinin $^{2}$ \\ - M.A. Al-Kuraan Tarek ${ }^{2} \bullet$ Sergiy Klymenko ${ }^{3}$ \\ 1 - Igor Sikorsky Kiyv Polytechnic Institute, Kyiv, Ukraine \\ 2 - Kremenchuk Mykhailo Ostrogradsky National University, Kyiv, Ukraine \\ 3 - V. Bakul Institute for Superhard Materials of the NAS of Ukraine, Kyiv, Ukraine
}

Received: 20 January 2020 / Accepted: 24 February 2020

\begin{abstract}
An approach to assessing the performance of carbide cutting inserts based on fixing changes in the defectiveness of its structure is proposed. The assessment is based on the phenomenon of activation of inhomogeneous chemical processes at extremely low concentrations of substances that occur in places of excessive surface activity in the structure of the material. The effect is determined by the initial imperfection of the structure of the surface layer of the material and the increase in the defectiveness of the carbide material under the influence of thermobaric loading during the operation of the tool. It is proposed to use the black index of the chemographic image of the studied object as a criterion for the array of structural defects, the value of which indicates the level of structural violations and internal defects in the material.
\end{abstract}

Keyword: chemography, hard alloy (carbide material), defective material structure, cutting time.

\section{Introduction}

The properties of sintered hard alloys are determined not only by their composition and structure, but also by the presence of various defects. Therefore, it becomes necessary to control the micro- and macrostructure of the alloy. The presence of caverns, cracks, structural imperfections and other defects in the hard alloy affects the operational stability of the finished products, the productivity of the processes with their application, and the reliability of operations.

Defects can conditionally be divided into two main groups that is sintering defects and processing defects. The development of such defects in the process of cutting leads to an active reduction in the period of tool life, the occurrence of marriage.

Typically, sintering defects, which include structural defects, are determined by $X$-ray diffraction analysis. Identification of cracks is performed using microscopy (including electron microscopy), using visualization tools. There are many methods for controlling hard alloys and superhard materials. Some of the methods are standardized [1], others are currently being actively developed [2]. The methods presented in [3, 4] make it possible to perform microscopic control of a hard alloy, but only indirectly allow one to judge the reliability of the operation of a tool with carbide inserts. At the same time, work [5] shows the possibilities in predicting the health of plates during their operation, in particular, of the tungsten group [6].

We propose to use the chemography method described by the authors in $[7,8]$ to assess the defectiveness of a hard alloy and predict its performance.

The method of chemography is based on the use of phenomena of activation and fixation of chemical heterogeneous processes of extremely low concentrations of substances (including aqueous solutions) that occur in places of excess surface activity of the body under study. To fix these reactions, the authors of [9] propose using a photographic film (X-ray type RT-1 or AGFAD7 NIF).

The researchers studied the indicated effect by the example of metals, the oxidation of which occurs in the presence of moisture with an intermediate product in the form of atomic hydrogen $\mathrm{H}^{+}$, the ingress of which on the surface of the film in the dark leads to the formation of atomic silver $\mathrm{Ag}^{+}$in it, just like when contact with the emulsion of light rays.

Due to chemical reactions in the film, a latent reflection of this interaction is formed. If the surface of a solid body, being oxidized during chemographic exposure (the contact time through a thin water gap of the oxidizing surface and the film) is spatially inhomogeneous to emit atomic hydrogen into the aqueous medium, the nature of the heterogeneity of such a process is recreated in the latent picture of the film, which is converted into a visible one by the usual manifestation.

An important point of the method for fixing reactions of ultra-low concentrations is its resolution. Despite the fact that atomic hydrogen $\mathrm{H}^{+}$practically affects $\mathrm{Ag}^{+}$, causing silver oxidation in $\mathrm{Ag}_{2} \mathrm{O}$ during the manifestation of silver, the resolution

$\bowtie$ Alexander Salenko

salenko2006@ukr.net 
will theoretically be determined by the size of silver particles (its grain), in practice, establish close contact with the test surface with a layer of $\mathrm{H}^{+} \mathrm{OH}^{-}$liquids almost difficult enough.

The metal surface freed from oxides in the initial stages is very sensitive to various factors: moisture, temperature, ion etching, deposition (adsorption) of atoms or molecules other than the elemental composition of the substrate, deformation, etc. Therefore, such a surface exhibits high chemical activity, a variable depending on the active factor. If the action of these factors is local, they will locally affect the rate of further oxidation of the investigated surface even during chemographic exposure and thus visualize themselves. At the same time, the manifestations of film are intensified by the formation of a latent image $10^{6}-10^{7}$ times. This allows you to use the chemographic method to visualize heterogeneous processes of ultra-low intensity and successfully apply it to study a wide class of phenomena: metal corrosion, the structure of chemically or mechanically processed surfaces, electrode processes, metabolism in biological tissues, etc.

\section{Experimental Methods}

For the study, T15K6+TiN hard alloy plates were used; they processed X18H10T stainless steel. Processing modes cutting speed of $85 \mathrm{~m} / \mathrm{min}$, feed $-0,07 \mathrm{~mm} / \mathrm{rev}$, cutting depth $-5,2 \mathrm{~mm}$. A shaft-type part was subjected to processing, external processing, to the passage. To exclude the influence of surface contaminants before chemographic studies, the plates were cleaned in a VUP-5 vacuum chamber using equipment for degassing the test samples (holding time 2 hours, vacuum depth $10^{-3} \mathrm{~Pa}$, heater temperature $425 \mathrm{~K}$.

The surface of the plates was studied using a REM-106 I scanning electron microscope, obtaining images of the surface layer in reflected electrons, and chemographic images were obtained according to the procedure [10].

Since chemographic patterns differed in the optical density of the image, a technique of averaging shades of gray was used. So, to assess the degree of influence of the acting factor on the chemographic image, we switched to the relative blackness index, which was calculated by

$$
I_{c}=\frac{F_{i}}{100-F_{\min }},
$$

where $F_{i}, F_{\min }$ - optical density of the $i$-th and minimum shades of gray.

Such an approach allows us to practically eliminate the influence of some deviations in the chemical composition of the medium, the modes of performing chemography, since we move from absolute indicators of the density of the obtained image to relative indicators.

To determine the optimal exposure time $\tau$, studies were performed that showed a change in the relative blackness index as a function of time. The results showed that exposure for $\tau=20$ min makes it possible to obtain the maximum value of image contrast, fig. 1.Moreover, it was found that an important role in identifying defects is played by the temperature of the liquid $d T$, which is selected depending on the required resolution of the resulting chemographic picture, fig. 2 .

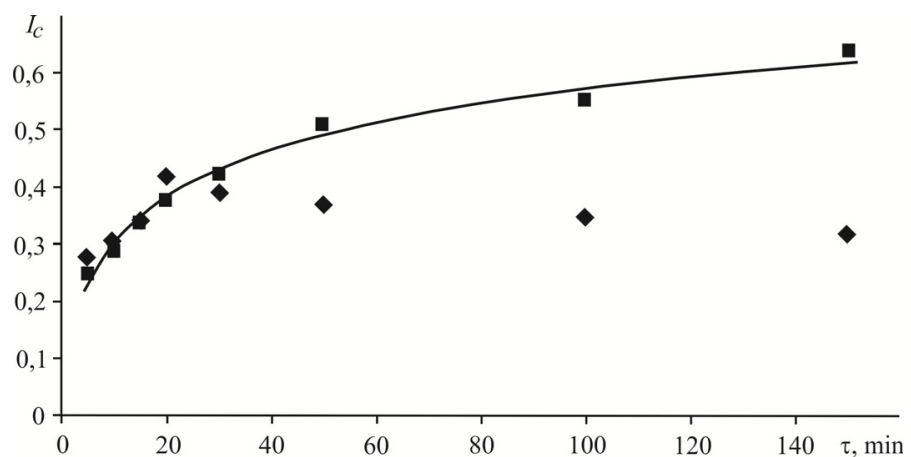

Fig. 1. The change in blackness $I_{c}$ when changing the exposure time: - blackness index $I_{c} ; \mathbf{-}$ - shades of gray by element; - logarithmic shades of gray by element

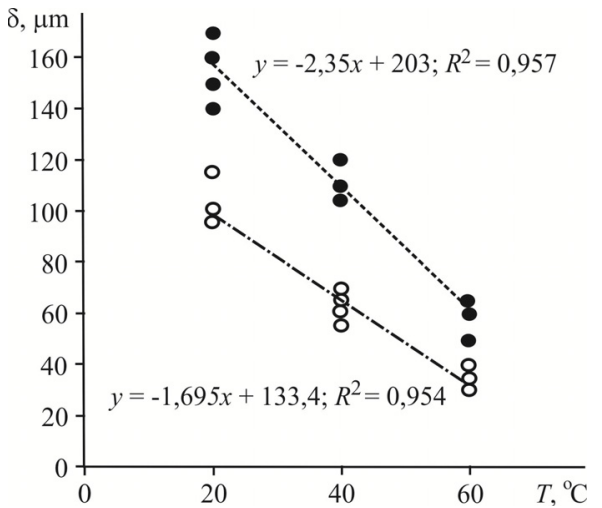

Fig. 2. Depending requiredresolution of the temperature of liquid: •-non-metals; o-metals; $\cdots$ - linear (nonmetals); - - - - linear (metals)

To minimize the degree of influence of the plate coating on the obtained chemographies, a preliminary determination of the coating thickness was performed using the NOVOTEST TP-1 coating thickness gauge. the resolution of the device with a sensor $\mathrm{F}-0.3 \pm 3 \%$ of the measured value (with a measured value in the range $0-300$ $\mathrm{mm}$ ). Since the active surface area of the sensor is $9 \mathrm{~mm}^{2}$, measurements were performed at fixed points along a line passing through the center of the plate. Thus, average values of the coating thickness $h$ were obtained both at the tops of 
the plate and at its working edges. The coating thickness was measured on new plates, as well as after a certain period of their work.

\section{Obtained Results}

An example image of the studied plates and a chemographic picture of the plate are shown in table 1.

Table 1

Chemographic images of T15K6 carbide plate with $\mathrm{TiN} *$ coating

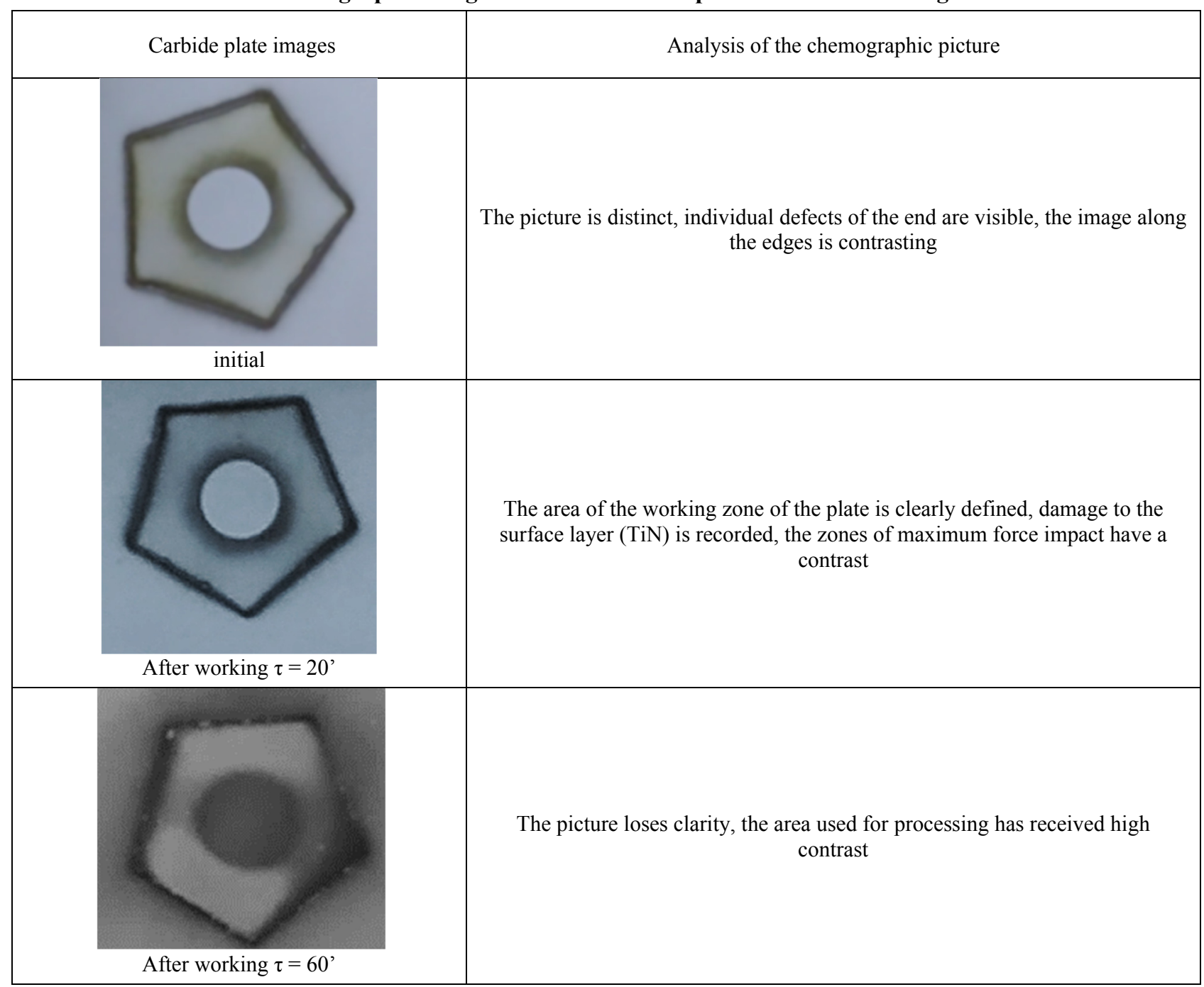

* Contamination from plates removed in a vacuum chamber

In contrast to the presented image, the chemography of the plate has clearly defined contours with a width of $0,4-$ $0,9 \mathrm{~mm}$, which differ from the presence of defects that are visually determined at the edges and vertices of the plate. The presence of a thin TiN layer does not significantly affect the black density, since a change in the coating thickness (from $2 \mathrm{~mm}$ to $10 \mathrm{mkm}$ with an average value of $6,0 \mathrm{~mm}$ before processing and from 0 to $8 \mathrm{~mm}$ with an average value of 4,0 $\mathrm{mm}$ after processing) led to a change in the parameter $I_{c}$. At the same time, we found that with an increase in the processing time for this plate, the chemographic picture of the plate changes: the borders become wider (over 1,5 mm). This width directly depends on the cutting conditions, and determines the chemographic activity of the surface.

Comparing the microelectronic image with the obtained chemographic image, we can conclude that the idle vertex (fig. 3) gives less illumination, while the vertex experiencing loads from the cutting process even more without damage to the coating is more active. We found that the chemographic picture will change with the growth and accumulation of critical damage to the hard alloy. So, if at the initial moment of time the maximum contrast of the image is observed only at the ends (in places where the planes converge), then during operation the index $I_{c}$ increases on those surfaces where the action of the process factors was maximum (fig. 4). 
Thus, obtaining a chemographic image of the initial plate and comparing it with the existing standard ones, we can evaluate the initial state of the material and predict the period of operation of the plate. In this case, a criterion for existing defects and structural imperfections can be a change in the blackness index, the minimum value of which indicates a minimum of structural disturbances and internal defects.

Since the material undergoes thermobaric loading on the contact surfaces during cutting, and the structure of the tool material differently resists this loading, it can be concluded that chemography fixes an increasing number of defects, which in some cases have a rather long latent accumulation and cannot be fixed by other known methods assessment of the state of the plates.

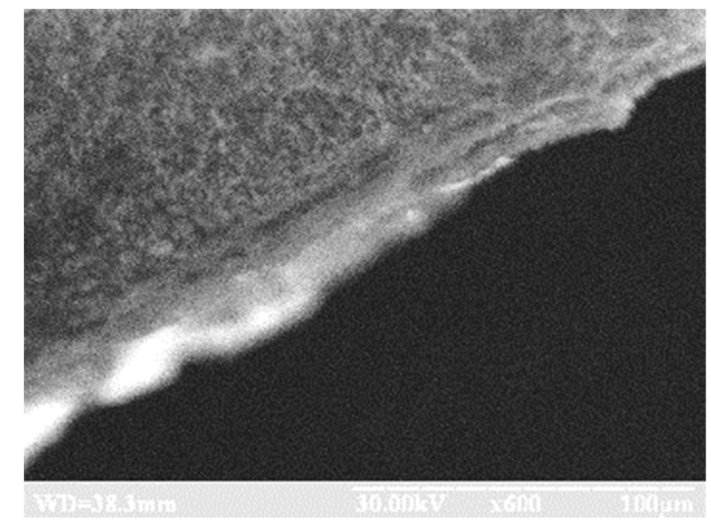

$a$

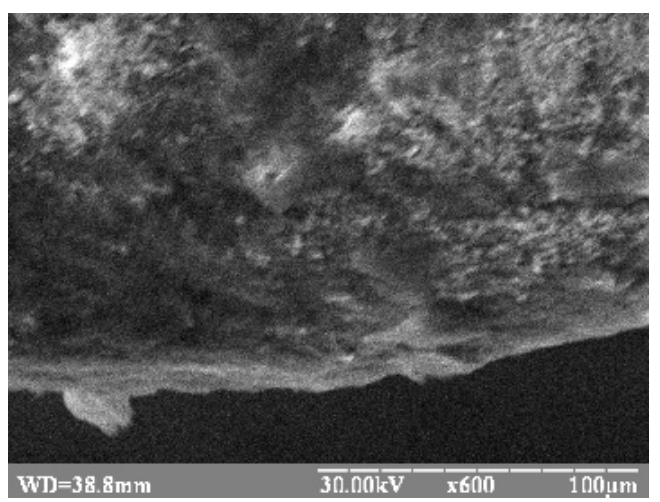

$b$

Fig. 3. Microelectronic images of initial $(a)$ and working vertices $(b)$

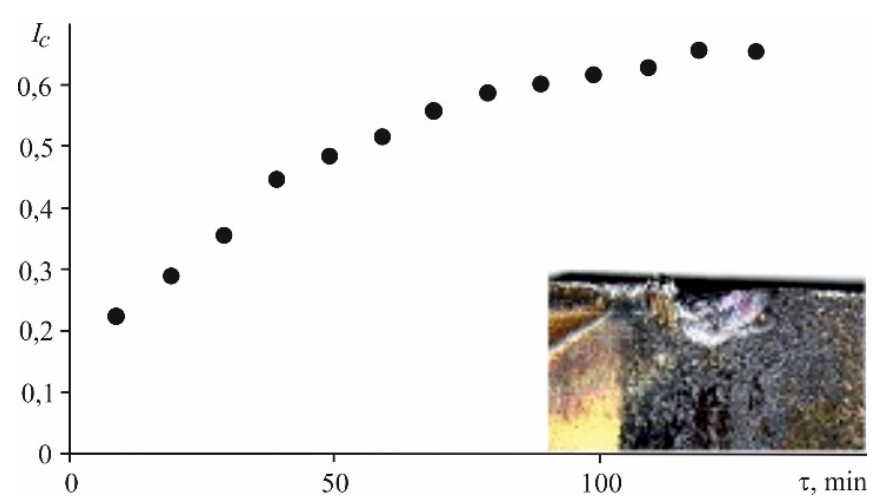

Fig. 4. Changing $I_{\mathrm{c}}$ from time of used (before the crack)

However, in practice, we are dealing only with the destruction elements that appeared after passing through the activation barrier. That is why chemography may be useful for quantitative assessment of the state of the material structure at the stage of "shadow" increase in the number of defects, when the entropy of the system increases without changing its properties. Indeed, in essence, the method registers changes occurring on surfaces at the atomic level.

\section{Conclusions}

The conducted studies allow us to propose a new highly effective method for assessing the performance of carbide plates based on the intensity of the chemographic effect fixed on the surface of the plates. In this case, this effect is determined by the initial imperfection of the surface layer structure (including the presence of defects) and the degradation of the cutting surface during processing.

Further research should be aimed at assessing changes in chemographic parameters depending on the conditions of thermobaric loading of the system and obtaining certain indicators that can be tied to the nature of the phenomena in the material. The result of such studies may be methods for predicting the operability of the tool in specific conditions. 


\title{
References
}

1. ASTM B294-17, Standard Test Method for Hardness Testing of Cemented Carbides, ASTM International, West Conshohocken, PA, 2017, www.astm.org

2. Annamaria Naughton Duszova and all. Small-Scale Mechanical Testing of Cemented Carbides from the Micro- to the NanoLevel: A Review. - April 2019. - Metals - Open Access. Metallurgy Journal 9(5):502. - DOI:10.3390/met9050502

3. Roebuck, B., Phatak, C., Birks-Agnew, I. A comparison of the linear intercept and equivalent circle methods for grain size measurement in WC/Co hardmetals. MPIF Cemented Carbide Symposium (Int. Conf. on PM 2004), Chicago, USA, June 2004.

4. Dary, F-C., Roebuck, B., Gee, M.G., Effects of microstructure on the thermo-mechanical fatigue response of hardmetals using a new miniaturised testing rig, Proc. 6th Int. Conf. on the Science of Hard Materials - Lanzarote, March 1998, Int J. of Refractory Metals and Hard Materials. - 1999. - No.17. - P. 45-53.

5. Tarrago J.M.. Damage tolerance of cemented carbides under service-like conditions A dissertation submitted to partial fulfilment of the requirements for the degree of Doctor of Philosophy Damage tolerance of cemented carbides under servicelike conditions A dissertation submitted to partial fulfilment of the requirements for the degree of Doctor of Philosophy. Barcelona, Spain. - 2016.

6. Tarragó J.M., Ferrari C., Reig B., Coureaux D., Schneider L., Llanes L. Mechanics and mechanisms of fatigue in a WC-Ni hardmetal and a comparative study with respect to WC-Co hardmetals. International Journal of Fatigue. -2015 . - No. 70, P. 252-257. DOI: 10.1016/j.ijfatigue.2014.09.011.

7. Elizarov M.A. Visualization of early stages of corrosion processes by a chemography method // Surface and Interface Analysis. 2006. - T. 38. - C. 263-266.;

8. Elizarov A.I., Sukachov A.V. New Method for Visualizing Heterogeneous Reactions // Vacuum. - 1999. - No. 54. - P. 233237.

9. Слізаров М.О. Візуалізація методом хемографіїпітингової корозії металевих плівок // Фізика і хімія твердого тіла. 2007. - T. 8, No. 4. - C. 831-835.

10. Слізаров М.О. Застосування фотоплівки для візуалізації гетерогенних реакцій надмалої інтенсивності // Фізика і хімія твердого тіла. - 2007. - Т. 8, № 3. - С. 597-600.

\section{Застосування хемографії для оцінки працездатності твердосплавних різальних пластин}

Олександр Саленко, Михайло Елізаров, Виктор Щетинін, М. А. Аль-Кураан Тарек, Сергій Клименко

Анотація: Запропонованій підхід до оиінки працездатності різальних пластин з твердого сплаву, заснований на фіксуванні зміни дефектності його структури. В основу оцінки покладено явіще актівації неоднорідніх хімічніх процесів при вкрай низьких концентраціях речовин, що виникає в місиях надлишкової поверхневої активності в структурі матеріалу. Ефект визначається початковою недосконалістю структури поверхневого шару матеріалу $і$ зростанням дефектності твердого сплаву під дією термобаричного навантаження в проиесі роботи інструменту. Як критерій масиву структурних дефектів запропоновано використовувати індекс чорноти хемографічного зображення досліджуваного об'єкта, значення якого вказує на рівень структурних порушень і внутрішніх дефектів в матеріалі.

Ключові слова: хемографія, твердий сплав, дефектність структури матеріалу, час різання

\section{Использование хемографии для оценки работоспособности твердосплавных режущих пластин}

\author{
Александр Саленко, Михаил Елизаров, Виктор Щетинин, \\ М. А. Аль-Кураан Тарек, Сергей Клименко
}

Аннотация. Предложен подход к оченке работоспособности режущчих пластин из твердого сплава, основанный на фиксации изменения дефектности его структуры. В основу оценки положено явление активации неоднородных химических процессов при крайне низких кониентрациях веществ, возникающей в местах избыточной поверхностной активности в структуре материала. Эффект определяется начальным несовершенством структуры поверхностного слоя материала и возрастанием дефектности твердого сплава под действием термобарического нагружения в проиессе работы инструмента. В качестве критерия массива структурных дефектов предложено использовать индекс черноть хемографического изображения исследуемого объекта, значение которого указывает на уровень структурных нарушений и внутренних дефектов в материале.

Ключевие слова: хемография, твердый сплав, дефектность структуры материала, время резания 


\section{References}

1. ASTM B294-17, Standard Test Method for Hardness Testing of Cemented Carbides, ASTM International, West Conshohocken, PA, 2017, www.astm.org

2. Annamaria Naughton Duszova and all. Small-Scale Mechanical Testing of Cemented Carbides from the Micro- to the NanoLevel: A Review, April 2019, Metals - Open Access, Metallurgy Journal, vol. 5, no. 9. DOI: 10.3390/met9050502

3. Roebuck, B., Phatak, C., Birks-Agnew, I. (2004), A comparison of the linear intercept and equivalent circle methods for grain size measurement in WC/Co hardmetals. MPIF Cemented Carbide Symposium (Int. Conf. on PM 2004), June, Chicago, USA.

4. Dary, F-C., Roebuck, B. and Gee, M.G. (1999), Effects of microstructure on the thermo-mechanical fatigue response of hardmetals using a new miniaturised testing rig, Proc. 6th Int. Conf. on the Science of Hard Materials - Lanzarote, March 1998, Int J. of Refractory Metals and Hard Materials, no. 17 pp. 45-53.

5. Tarrago, J.M. (2016), Damage tolerance of cemented carbides under service-like conditions A dissertation submitted to partial fulfilment of the requirements for the degree of Doctor of Philosophy Damage tolerance of cemented carbides under servicelike conditions A dissertation submitted to partial fulfilment of the requirements for the degree of Doctor of Philosophy, Barcelona, Spain.

6. Tarragó, J.M., Ferrari, C., Reig, B., Coureaux, D., Schneider, L. and Llanes, L. (2015), "Mechanics and mechanisms of fatigue in a WC-Ni hardmetal and a comparative study with respect to WC-Co hardmetals", International Journal of Fatigue no. 70, pp. 252-257, DOI: 10.1016/j.ijfatigue.2014.09.011

7. Elizarov, M.A. (2006), "Visualization of early stages of corrosion processes by a chemography method", Surface and Interface Analysis, no. 38, pp. 263-266;

8. Elizarov, A.I. and Sukachov, A.V. (1999), "New Method for Visualizing Heterogeneous Reactions", Vacuum, no. 54, pp. 233-237.

9. Elizarov, M.O. (2007), "Vizualisatsija metodom chemografii pitingovoi korozii metalrvyh plivok", Fizika I chimija tverdogo tila, vol. 8 , no. 4 , pp. 831-835.

10. Elizarov, M.O. (2007), "Zastosuvannja fotoplivki dlja visualizatsii geterogennih reaktsii nadmaloy intensivnosti”, Fizika I chimija tverdogo tila, vol. 8, no. 3, pp. 597-600. 